\title{
The challenges and opportunities of transboundary cooperation through the lens of the East Carpathians Biosphere Reserve
}

\author{
Tanya D. Taggart-Hodge ${ }^{1}$ and Michael Schoon ${ }^{2}$
}

\begin{abstract}
A significant challenge of our time is conserving biological diversity while maintaining economic development and cultural values. The United Nations Educational, Scientific and Cultural Organization has established biosphere reserves within its Man and the Biosphere program as a model means for accomplishing this very challenge. The East Carpathians Biosphere Reserve (ECBR), spreading across Poland, Slovakia, and Ukraine, represents a large social-ecological system (SES) that has been protected under the biosphere reserve designation since 1998. We have explored its successes and failures in improving human livelihoods while safeguarding its ecosystems. The SES framework, which includes governance system, actors, resources, and external influences, was used as a frame of analysis. The outcomes of this protected area have been mixed; its creation led to national and international collaboration, yet some actor groups remain excluded. Implementation of protocols arising from the Carpathian Convention has been slow, while deforestation, hunting, erosion, temperature extremes, and changes in species behavior remain significant threats but have also been factors in ecological adaptation. The loss of cultural links and traditional knowledge has also been significant. Nevertheless, this remains a highly biodiverse area. Political barriers and institutional blockages will have to be removed to ensure this reserve fulfills its role as a model region for international collaboration and capacity building. These insights drawn from the ECBR demonstrate that biosphere reserves are indeed learning sites for sustainable development and that this case is exemplary in illustrating the challenges, but more importantly, the opportunities that arise when ensuring parallel care and respect for people and ecosystems through the model of transboundary protected areas around the world.
\end{abstract}

Key Words: biosphere reserves; conservation; East Carpathians; Poland; protected areas; Slovakia; social-ecological system; sustainable development; transboundary parks; Ukraine

\section{INTRODUCTION}

The United Nations Educational, Scientific and Cultural Organization (UNESCO) established the Man and the Biosphere (MAB) program in the early 1970 s as a means to conserve biological diversity, promote economic development, and maintain associated cultural values (UNESCO 1996, Fall 1999). The first biosphere reserves (BRs) were created in 1976, primarily for conservation and research (Sourd 2004). In the 1980s, their emphasis shifted toward sustainable use and cooperation with local people (UNESCO 2003). Today, there are $631 \mathrm{BRs}$ in 119 countries worldwide (UNESCO 2016a). Some argue that BRs hold the key to a much needed paradigm shift toward sustainability (Breymeyer and Dabrowski 2000); at a minimum, they begin to address some of the concerns listed in Agenda 21, the comprehensive global plan of action that resulted from the United Nations Conference on Environment and Development (United Nations Division for Sustainable Development 1992). These concerns include "the deterioration of the ecosystems on which we depend for our well-being [...], social and political tension, [and] a perpetuation of disparities between and within nations" (United Nations Division for Sustainable Development 1992:3). A 10-year action plan for MAB has recently been endorsed (UNESCO 2016b).

The first mention of transboundary biosphere reserves (TBRs) was made in the early 1960s, at the first World Conference on National Parks, and was revisited at the same conference a decade later (UNESCO 2003). It is at this moment that the recommendation for close collaboration between governments with neighboring parks was made (UNESCO 2003). In 1992, the International Coordinating Council of the MAB program enacted the first two TBRs (UNESCO 2003). Improving the relationship between people and their environment under the umbrella of a BR now transcended political borders. There are currently 14 TBRs worldwide (UNESCO 2016a).

TBRs are unique and promising (Denisiuk et al. 1997); not only are they recognized internationally, but they represent a commitment from the respective countries toward the "Seville Strategy" and "Statutory Framework of the World Network of Biosphere Reserves," major MAB documents created in 1995 that prioritize biodiversity conservation, sustainable development for local people, and research and education (UNESCO 1996, 2001, $2016 b$ ). These documents contain the primary objectives for all TBRs (UNESCO 2003). To this effect, Batisse states that "biological diversity ignores political boundaries and should be managed accordingly" (1997:15). TBRs are ideally situated to be analyzed through a social-ecological lens because they are set up with social and ecological goals in mind.

The "Seville Strategy" emphasizes the significant challenge of balancing biological conservation with sustainable use, or put more simply: conservation and development (UNESCO 1996). This task can only be accomplished effectively if it involves "natural and social scientists; conservation and development groups; management authorities and local communities - all working together on this complex issue" (UNESCO 1996:3). This holds true, and is even more exigent, with TBRs because of the need to accommodate and use constructively the differing management units and legislative frameworks of adjacent independent countries, each with their own rules, practices, and traditions (Fall 1999).

${ }^{1}$ School of Environmental Studies, University of Victoria, ${ }^{2}$ Center for Behavior, Institutions and the Environment and School of Sustainability, Arizona State University 
One of the earliest formal descriptions of the benefits of transboundary conservation efforts advocated for its efficacy along three streams, namely, biodiversity conservation, economic development, and the promotion of peace, echoing the calls for BRs (Hanks 2003). In the years since the articulation of this position, few studies have conducted baseline research to monitor the before-and-after benefits of transboundary initiatives or improvements over time. One of the few exceptions to this is Saleem Ali's book Peace Parks (2007), which looks at how transboundary conservation can contribute to peace building and provides several case studies on the value of such efforts. Others report similar overall benefits (Conca and Dabelko 2002) or specific changes in cross-border governance (Schoon 2012). On the economic front, Büscher (2013) examines how it is not clear that economic development will actually follow from transboundary conservation and highlights how power dynamics may further existing income inequalities. Finally, in many cases, the most important argument for transboundary conservation is for improved biodiversity outcomes, by better managing at the scale of the ecosystem (Harrison and Bruna 1999, Evans et al. 2014), providing for cross-border ecosystem service provision (López-Hoffman et al. 2010), and allowing the reopening of migratory paths (Van Aarde and Jackson 2007), among other potential conservation benefits. However, none of these studies systematically examine the case for transboundary conservation with clear, empirical evidence.

Conserving biological and cultural diversity while promoting economic and social development is an enormous challenge; the Eastern Carpathians Biosphere Reserve (ECBR) located within the largest and least altered mountain range in Central Europe, the Carpathian range, serves as a fine model for testing the effectiveness of TBRs. This is primarily because this protected area spans across three countries (Poland, Ukraine, and Slovakia) with multiple national and landscape parks within each jurisdiction, in turn highlighting the complex political, biological, and cultural interactions simultaneously at play (ECBC [date unknown], 2004, Stein et al. 2006). The ECBR was created in 1998 and was the first trilateral BR in the world (MAB 2007). It had in fact been proposed in 1990, but took 8 years to be created. The 1998 amalgamation combined the existing Polish-Slovak reserve, which had been formed in 1992, with the Ukrainian component (MAB 2007). When discussing the history of the areas later included into the ECBR, Niewiadomski describes that "the state borders in this region have often changed, with some areas of the ECBR belonging in succession to six or seven different countries within the living memory of a single generation" (2011:26).

The UNESCO-MAB BR nomination does not impose any special legal status or improved protective status other than that already granted by national legislation. The legal context of each BR is left in the hands of national governments. In Poland and Slovakia, BRs are not associated with any protected area category, resulting in BRs having no legal context there. On the other hand, Ukraine has a distinct protected area category for BRs; however, the legal provisions attached do not align with the UNESCO BR concept. BRs in Ukraine are perceived as strict nature reserves rather than areas for both conservation and sustainable use of resources. There are no regional policies solely focused on mountain areas in Poland, primarily because of the fact that lowlands prevail in Poland. In contrast, Ukraine did draft a special law supporting development in mountain areas but could never afford to implement this legal act (Supreme Council of Ukraine 1995).

The unique location and trilateral nature of this case study distinguishes it from other studies of large complex socialecological areas illustrated within the literature to date (Evans et al. 2014, Fleischman et al. 2014a, b, Villamayor-Tomas et al. 2014). We ask whether the ECBR has served to improve human livelihoods while safeguarding its natural ecosystems. In doing so, we examine the ECBR, not only as a single, region-specific example of a BR, but also as a social-ecological system (SES). We also use it to address current shortcomings in the transboundary conservation literature that has tended to focus on specific aspects of the system, i.e., ecological, economic, or social, and potentialities rather than baseline metrics. We use the SES framework, as detailed subsequently, to address these goals.

\section{METHODS}

The methods we used were aligned with the Social-Ecological System Meta-Analysis Database (SESMAD) project, which builds on an SES framework originally proposed by Ostrom in 2007 and published in 2009 (Ostrom 2009, Cox 2014, McGinnis and Ostrom 2014). The purpose of SESMAD is to systematically collect information on the social and ecological attributes of large-scale SESs through content analysis of published studies (Cox 2014). We have modified the SESMAD framework in two ways. First, because this research examines natural resources, we revert to the category of "resources" rather than environmental commons. We do not distinguish between resource units and resource systems as in the original Ostrom frame, because the differentiation was not conducive to further insights in this case. Second, in line with Schoon and Cox (2012), we also look at external influences that affect the system. Our research represents the compilation of information relating to the ECBR as a case study that can later be analyzed under the SESMAD project. We have thus structured it around a modified view of SESs similar to Cox (2014): resources, governance system, actor group, and outcomes, as well as adding a discussion of external influences, which were particularly relevant to our research. External influences refer to the social, economic, and political influences that affect the SES from beyond the defined boundaries of the SES, similar to the nested systems referenced in Ostrom (2009), which are important because of their influence on a system yet are viewed as outside of the particular SES under study.

Relevant peer-reviewed and gray literature was examined to develop an understanding of the ECBR's successes and challenges over time. Articles, reports, and other documentation were retrieved between September 2013 and July 2015 through Google Scholar and through multiple discussions with Zbigniew Niewiadomski, who coordinated cooperation in this trilateral TBR for 15 years. He was also a member of the International Advisory Committee for Biosphere Reserves to the UNESCO Director General and one of the fathers of the "EUROPARC Transboundary Parks - Following Nature's Design" certification scheme, a system that was launched in 2003 at the World Parks Congress in Durban, South Africa, intended to analyze the quality of transboundary cooperation in European countries (Karivalo 2009, EUROPARC 2015). We recognize Alicia Breymeyer's role as an international champion for TBRs, particularly in Poland (Breymeyer 1997). We also draw on the Carpathian Protected Area Management Effectiveness Tracking 
Fig. 1. East Carpathians Biosphere Reserve (source: Z. Niewiadomski). MAB, Man and the Biosphere; UNESCO, United Nations Educational, Scientific and Cultural Organization.

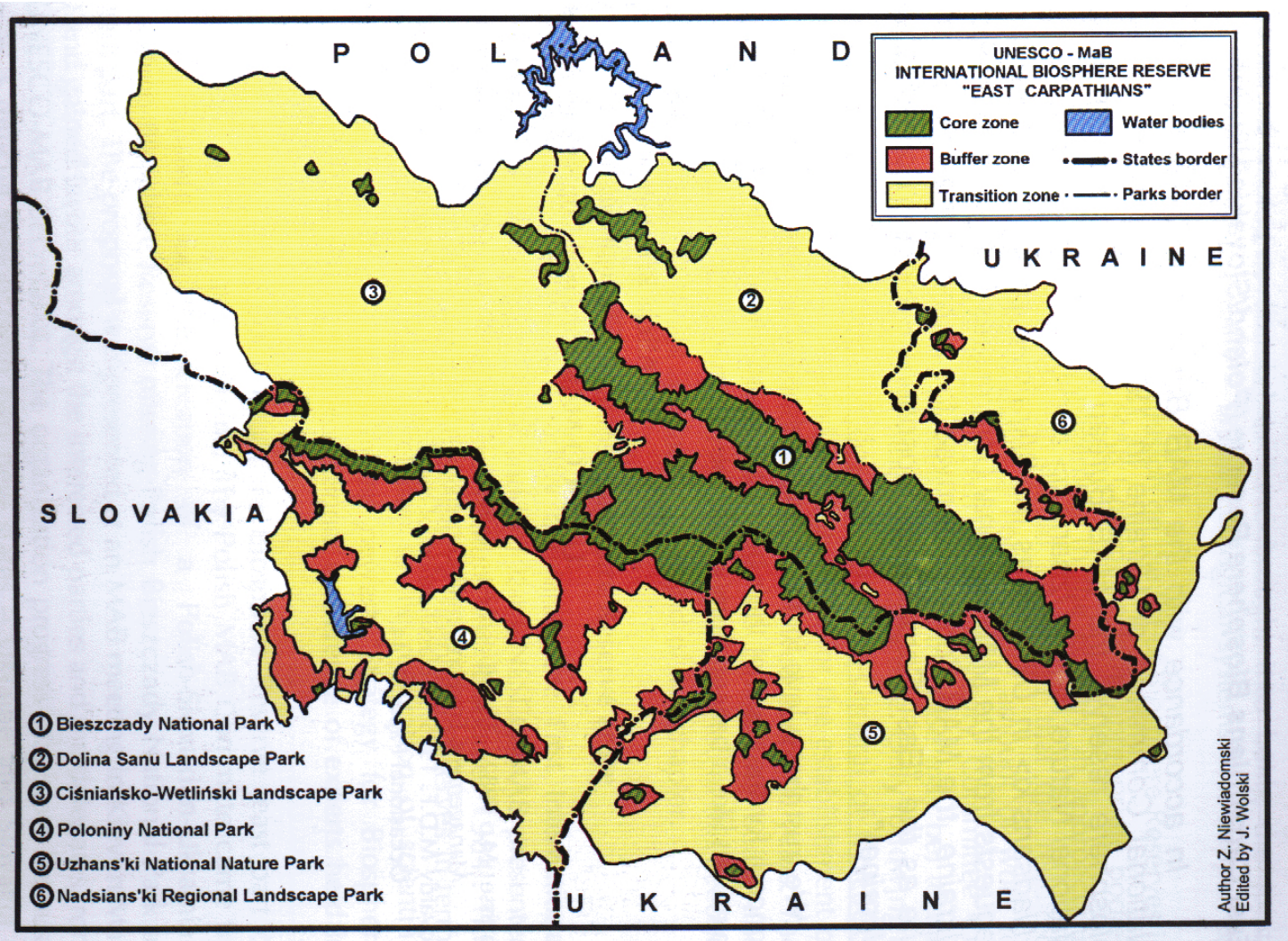

Tool (CPAMETT) database, which enabled a systematic tracking of social and ecological threats to the protected area complex and the protected areas' overall performance across a range of metrics.

\section{RESULTS}

\section{Resources}

The ECBR contains the continental divide, separating the Baltic and Black Seas' watersheds and is the largest European mountain biosphere found outside the Russian Federation (Fig. 1; Niewiadomski 2011). Two major rivers originate in the ECBR: the Dniester and San (Niewiadomski 2011). Freshwater is one of the most important natural resources found within the Carpathian Mountains, with $80 \%$ of it draining into the Danube River (WWF 2016b). The magnitude of this river basin's volume of water, which drains into 18 countries across Europe, is irreplaceable through technological means (WWF 2016b). Charcoal of an anthropogenic origin is also present in the region (Kukulak 2014).

The ECBR's mountain peaks reach $1346 \mathrm{~m}$ at their highest point, and although they contain 4 distinct vegetation types, are for the most part afforested (Table 1; EuroMAB 1993, Niewiadomski 2011). Some of these beech-fir forests have been protected since 1728 yet were not on the World Heritage List until 2006 (Niewiadomski 2011, Commarmot et al. 2013). There are more than 100 species of birds that live within the reserve (Table 1), and a similarly high diversity of flora can be found within its borders, many of which are endemic species (Ruzickova et al. 1998, ŠOP SR 2010, Otýpková et al. 2011). In the Slovak region alone, more than 1200 species of vascular plants have been identified, with a significant portion of these being endangered (ŠOP SR 2010). The ancient English yew (Taxus baccata L.), among many others, is now endangered (Dovčiak 2002).

Table 1. Examples of resources found in the East Carpathians Biosphere Reserve.

\begin{tabular}{ll}
\hline \hline Resource & Scientific Name \\
\hline Beech forest & Fagus sylvatica \\
Beech-fir forest & Fageto- Abietum \\
Dwarf shrublands with green alder & Alnetum viridis \\
Belt of treeless poloniny, subalpine meadows & Prata subalpine \\
Brown bear & Ursus arctos \\
European bison & Bison bonasus \\
Eurasian lynx & Lynx lynx \\
Eurasian beaver & Castor fiber \\
Primitive Hutzul horse & Equus ferus caballus \\
Wildcat & Felis silvestris \\
Red deer & Cervus elaphus \\
Wolf & Canis lupus \\
Black Stork & Ciconia nigra \\
Golden Eagle & Aquila chrysaetos \\
English yew & Taxus baccata \\
\hline Sources: Jaworski et al. (2002), Perzanowski et al. (2004), MAB (2007), \\
Perzanowski and Olech (2007), Durak (2010), and Niewiadomski (2011).
\end{tabular}


Significant numbers of fungi have been identified within the ECBR, as well as more than 200 species of lichens (ŠOP SR 2010). Fungal diversity was studied in Poloniny National Park (PNP) in Slovakia where researchers found 62 taxa of microfungi, 35 of which had never been recorded in this park before and 15 of which were entirely new to Slovakia (Adamcík et al. 2007). Although up to $20 \%$ of Europe's 75,000 species of fungi may be threatened (Senn-Irlet et al. 2007), PNP contains at least 17 of these rare and threatened species.

This is a culturally and historically significant region, where human populations and their influences on ecosystems have fluctuated over time. The Natura 2000 network, which protects threatened and rare ecosystems throughout Europe, has its largest Carpathians site in the ECBR (Niewiadomski 2011). Land planning, nature protection, and population trends are very different within each country's share of the reserve (Oszlányi et al. 2004, Kuemmerle et al. 2006). In Poland and Slovakia, population densities within the reserve boundaries are low. This is mainly because of the fact that many inhabitants of these regions, especially in Poland, sided with the national Ukrainian movement for independence during the Second World War (UNESCO 2003). Their efforts were crushed following the end of the war, leading villagers to be removed (UNESCO 2003). Niewiadomski (2011:27) explains that "the Nazis exploited the sovereignty aspirations of the Ukrainians and instigated them towards the extermination of Jews and Poles between 1941 and 1944 [...] the Polish and Soviet communist regimes retaliated in 1944 with the decision to deport all inhabitants of Ukrainian origin [...] and the Polish side remained a deserted 'prohibited zone' with no remaining settlements." The building of a dam on the Slovak side in 1987 led to the removal of additional people (UNESCO 2003). This may have been the only area of temperate Europe that had been spared any human activity for half a century, leading to fascinating succession in plants, birds, and mammals. Niewiadomski (2011:27) explained that "the area also preserves rich cultural heritage such as sacral wooden architecture dating back to 1645 or the narrow-gauge forest train built in the late 19th century." The remains of human influences, such as old farm sites, graveyards, ornamental shrubs, and the introduced beech made the ECBR a significant reference point in understanding the dynamics of the modern central European ecosystem.

Poland was the first country to recognize Ukraine's independence, less than 24 hours following the December 1, 1991, referendum, and developed a strategic partnership intended to promote the rapprochement of Ukraine and the European Union (EU), which solidified ties between Poland and Ukraine (Niewiadomski 2011). It is the very act of engaging in transboundary cooperation that established friendly relationships between "nations that lost tens of thousands of people in armed ethnic conflicts in the 1940s and were additionally separated by a border fence under the Communist regime" (Niewiadomski 2005, as cited in Niewiadomski 2011:26). Poland and the Slovak Republic joined the EU in 2004, leading them to prepare their portions of the ECBR for the Natura 2000 designation, a move that was not mirrored in Ukraine as a nonmember of the EU (Niewiadomski 2011). Preparations for the Natura 2000 designation facilitated research in the two countries and helped focus efforts on sustainable use; however, this did little to spur additional transboundary cooperation. Many activities over the past decade were thus focused on facilitating cooperation with Ukrainian partners (Niewiadomski 2011). Interestingly, the Ukrainian area had been divided into designated nature reserves since 1908 when it was part of the Austro-Hungarian Empire (UNESCO 2003). Ironically, it has since become the most densely populated of the three areas, with farming and forestry as the dominant economic activities (UNESCO 2003).

Political turbulence in Poland between 2005 and 2007 led to a shift in the government's attitude toward international cooperation, leading to changes in park staff but no apparent change in terms of the parks' approach to nature conservation (Niewiadomski 2011). Overall, it has been noted that there remains little collaboration between the managerial bodies for the reserve within each country, funding is inadequate, and there remain few formal measures of enforcement (WWF 2016b). Today, ongoing cooperation occurs at the annual scientific conference held in Poland through the presentation of scientific results and at the fairly recently established ECBR Coordinating Council, which was created in response to recommendations by UNESCO's MAB committee (ŠOP 2013). The advancement of cooperation remains challenging with meetings occurring so seldom. We did not find any details as to how this new Coordinating Council differs from the one that existed but failed 25 years ago when the ECBR was first created.

\section{Governance system}

Ministers of Poland, the Slovak Republic, and Ukraine signed a trilateral protocol in 1991 and created a Coordinative Council (Niewiadomski 2011; Table 2). This council met only a few times in the early 1990s and had no operational budget (Niewiadomski 2011). The International ECBR Scientific Council was intended to be an advisory body to the Coordinative Council, but it never met, eventually leading to the abandonment of this entire coordinating structure (Niewiadomski 2011). Thus, there is no official governing body for the entire BR (UNESCO 2003), nor is there a joint management plan; instead, each protected area is subject to its applicable national legislation, which dictates the standards for the establishment of management plans in its respective country.

Table 2. Time line of key milestones for the governance of the East Carpathians Biosphere Reserve.

\begin{tabular}{ll}
\hline \hline Year & Milestone \\
\hline 1991 & $\begin{array}{l}\text { Trilateral protocol signed and creation of Coordinative } \\
\text { Council }\end{array}$ \\
2003 & $\begin{array}{l}\text { Carpathian Convention signed } \\
\text { Carpathian Convention ratified and first Conference of the } \\
2006\end{array}$ \\
2008 & $\begin{array}{l}\text { Parties meeting } \\
\text { Thematic protocol on sustainable use of biological and } \\
\text { landscape diversity } \\
\text { Thematic protocol on sustainable forest management }\end{array}$ \\
2011 & $\begin{array}{l}\text { Thematic protocol on sustainable tourism } \\
\text { Thematic protocol on sustainable transport }\end{array}$ \\
2015 & $\begin{array}{l}\text { First national action plan under the Carpathian Convention } \\
\text { drafted }\end{array}$ \\
\hline
\end{tabular}


Table 3. Protected areas and responsible management agencies present in the East Carpathians Biosphere Reserve.

\begin{tabular}{|c|c|c|}
\hline $\begin{array}{l}\text { Poland } \\
113,847 \text { ha }\end{array}$ & $\begin{array}{l}\text { Slovak Republic } \\
40,778 \text { ha }\end{array}$ & $\begin{array}{l}\text { Ukraine } \\
58,587 \text { ha }\end{array}$ \\
\hline \multicolumn{3}{|l|}{$\overline{\text { Protected areas }}$} \\
\hline Bieszczady National Park (1973) & Poloniny National Park (1997) & Uzhanskyi National Nature Park (1999) \\
\hline Cisna-Wetlina Landscape Park (1992) & Poloniny National Park buffer zone & Nadsyanskyi Regional Landscape Park (1998) \\
\hline \multicolumn{3}{|l|}{ San River Valley Landscape Park (1992) } \\
\hline \multicolumn{3}{|l|}{ Responsible management agencies ${ }^{\dagger}$} \\
\hline Park authorities for national park & Poloniny National Park Administration & Uzhanskyi National Park Administration \\
\hline State Ministry of the Environment & $\begin{array}{l}\text { State forestry department for policy decisions } \\
\text { related to national park }\end{array}$ & State forestry departments for landscape parks \\
\hline $\begin{array}{l}\text { State forestry departments and landscape park } \\
\text { authority for landscape parks }\end{array}$ & & \\
\hline
\end{tabular}

The ECBR does, however, fall under the Framework Convention on the Protection and Sustainable Development of the Carpathians (Carpathian Convention 2003), signed in 2003 and enacted in 2006, which has been described as a "a multi-level governance mechanism covering the whole of the Carpathian area [...] for the protection and sustainable development of a mountain region" (Carpathian Convention [date unknown], "The Convention"; see Table 2). The Government of Ukraine is its depositary, yet each party contributes to the regular budget of the convention (Carpathian Convention 2003). The highest body of the convention, the Conference of the Parties (COP), holds meetings every 3 years, the last (COP4) of which was held in 2014 (Carpathian Convention [date unknown], "Conference of the Parties"). The Carpathian Convention facilitates rather than regulates cooperation (Carpathian Convention 2003). Since its creation, it has adopted formal thematic protocols (Parties to the Carpathian Convention 2008, 2011a, b, 2014a, b, Beckmann 2013, Carpathian Convention [date unknown], "Conference of the Parties"; see Table 2). These thematic protocols in turn require international strategic action plans and national action plans. Until such extensive sets of documents for each work area of the convention are adopted and binding, on-the-ground implementation of legal obligations at the international level does not necessarily depend on the obligations deriving from the convention, but instead depends on existing legal acts within each respective country. The Carpathian Convention includes key features such as the polluter pays and precautionary principles, an ecosystem and programmatic approach, integrated planning and management of land and water resource, public participation and stakeholder involvement, and the preservation of cultural heritage and traditional knowledge (Carpathian Convention 2003). The Carpathian Convention supports the effectiveness of the ECBR through its eighth objective, which is "consultation, harmonisation and coordination of measures undertaken in border areas" (Parties to the Carpathian Convention 2014a:21).

To date, the Carpathian Convention has been criticized for simply producing documents rather than effecting real changes on the ground (Beckmann 2013). Fall (1999) foreshadowed that management plans were a long way off for this region in the late 1990s because of setbacks and internal political problems arising. For instance, Fall (1999) noted that metallic fences guarding the Ukrainian border made it hard for animals to pass through, although Niewiadomski (personal communication) pointed out that these fences did prevent animals from crossing into the zone between the state border and border fences, where poaching and illegal hunting had been witnessed.

The management agencies for the ECBR have been summarized in Table 3. According to national legislation, Bieszczady and Uzhanskyi are the only two of the six protected areas within the reserve that have exclusive management rights within their boundaries, which is accompanied by staffing and budgetary capacity (Niewiadomski 2011). The other four protected areas have limited operational and cooperation capacities (Niewiadomski 2011). The vast majority of forested areas in the ECBR are state owned, with some being managed by national park administrations and others by state forest administrations ( $Z$. Niewiadomski, 2003, personal communication).

\section{Actors}

Transboundary cooperation in the ECBR has been managed primarily by members of the administration of the various protected areas throughout the TBR (Niewiadomski 2011). These state employees are an important actor group as they are the dayto-day managers of the parks and play an instrumental role in ensuring that the "Seville Strategy" objectives are met. Because forestry is the main economic activity at the regional level (Niewiadomski 2011), an important user group is foresters. The commercialization of charcoal made from beech trees also occurs in the region (Uvarov 2000), although it is unclear from the literature how large this industry is today. The predominant employers on the Polish side are forestry and tourist services, whereas subsistence agriculture and forestry dominate on the Slovak side (Niewiadomski 2011). Farmers represent a key actor group because agriculture is restricted to cattle raising, sheep breeding, and small-scale farming that utilizes traditional landuse patterns (MAB 2007, Niewiadomski 2011). Traditional village systems remained an important part of the forest landscapes in a 2007 study, yet they were endangered as a result of the shift toward a market economy (Elbakidze and Angelstam 2007). One cannot 
ignore employees of the tourism industry, as well as tourists themselves, as key economic drivers, especially because of the expansion of this industry (MAB 2007). Governments, nongovernmental organizations, forest administrations, and scientific institutions are other key partners involved in cooperation (Niewiadomski 2011).

\section{External influences}

In 1995, the Foundation for Eastern Carpathians Biodiversity Conservation (ECBC) was established in Switzerland as a means to support transboundary cooperation through the promotion of activities that would protect biodiversity throughout the reserve (Fall 2003, MAB 2007). The foundation received US\$600,000 in seed funding from the World Bank Global Environment Facility and the MacArthur Foundation enabling its registration ( $\mathrm{Z}$. Niewiadomski, 2008, personal communication). The intent was for this seed money to stimulate other donors, namely, the three involved governments using foreign aid funds, to accomplish the above-mentioned program's goals (Z. Niewiadomski, 2008, personal communication). No other capital than the seed funding has ever been provided.

A permanent office for the foundation was established in 2001, with its board becoming a coordinating body for the ECBR and the main stakeholders being represented on the board itself. In 2003, the foundation managed to gather, for the first time ever, representatives from all six protected areas in the ECBR at a meeting in Czarna, Poland (Niewiadomski 2011). The foundation supported thematic expert working groups with its initial grant program, which elaborated and planned the implementation of transboundary action plans (Niewiadomski 2005, 2011). As was stated by UNESCO (2003:34), "The foundation remains the only legally established body for trilateral consultations and cooperation [and] its annual meeting also provides the only established - and fully funded - meeting between the three sides." Unfortunately, the needed additional funding was never raised, the trilateral program lost its appeal among governments, and the Eastern Carpathians Forest Biodiversity Conservation program was never formalized (Z. Niewiadomski, 2008, personal communication). There was not sufficient funding to run a Swissbased foundation that supported the East Carpathians. In 2006, the foundation suspended its programs, and the Polish office was closed (Niewiadomski 2011).

Nevertheless, the ECBC based in Switzerland did make a significant contribution to the ECBR in its 11 years of existence; it safeguarded its original endowment, supported more than 40 projects in the region, and coordinated cooperation with the 3 involved countries. Having a regional environmental trust fund reinforced the shared responsibility for natural resources across borders (Niewiadomski 2011). It appears that such a trust fund would have required a larger preliminary endowment, such as US\$3 million to US\$5 million, to ensure its viability ( $\mathrm{Z}$. Niewiadomski, 2008, personal communication). The ECBCfunded projects ranged in scope from biodiversity conservation to cultural heritage, research, sustainable tourism, and education (Niewiadomski 2011). The ECBC was also formally involved in the negotiations for the Carpathian Convention and associated protocols and collaborated with the Interim Secretariat of the Convention to create the Carpathian Network of Protected Areas (Z. Niewiadomski, 2008, personal communication).
In 2008, the board of the foundation proposed that the foundation's work continue by being replaced with a new successor foundation in Poland. It would be entrusted with the ECBC's original mission but would be in a more favorable position for receiving European funding (Z. Niewiadomski, 2008, personal communication). It appears that the ECBC is currently still being closed in Switzerland, and a daughter foundation has instead been established in the Slovak Republic; new projects have been supported in all three countries (Z. Niewiadomski, 2008, personal communication).

The World Wildlife Fund's (WWF) Ecoregion Initiative, a partnership promoting conservation and sustainable development in the Carpathians, named the East Carpathians one of its model project areas and highlighted a greenway trails project linking the three countries and encouraging tourism as a success story (WWF 2001).

\section{Ecological and social outcomes}

Even though the ECBR has been recognized on numerous occasions for its outstanding significance (Bihun et al. 2008, Geyer et al. 2009, Austrian MAB Committee 2011, Parties to the Carpathian Convention 2014c), the social and ecological outcomes appear to be mixed as a result of its creation. Furthermore, there was a paucity of available literature on social outcomes. What follows is therefore an account of the history and current situation of the ECBR rather than explicit outcomes of its creation.

One of the main arguments for establishing TBRs is that the act of combining multiple protected areas increases the scale of protection, which results in the maintenance of biodiversity, in particular migratory species that require large amounts of land (UNESCO 2003). There is no doubt that the 213,211 ha (MAB 2007) that make up the ECBR have provided habitat for an astonishing array of biodiversity (Kuemmerle et al. 2007). However, the results of dendroecological studies (Dittmar et al. 2003) shed light on the vulnerability of species such as the common beech in the face of climate change, regardless of whether they are located within or outside a protected area.

We chose to analyze the state of the primeval beech (Fagus sylvatica L.) forest as a proxy for the ecological outcomes of the reserve. It must first be acknowledged that it was not possible for us to assess the significance of climate change in comparison with other human-caused effects on beech forests. Nevertheless, the primeval beech forests that are present in the ECBR today represent a legacy of regional human-influenced interactions. Beech appears to be highly competitive, which hints toward its capacity to outlive longer suppression periods compared with other species, such as the silver fir (Abies alba Mill.; Commarmot et al. 2013). Nevertheless, the contemporary theory that beech and fir naturally undergo a cyclical rotation in this region is beginning to be questioned as recent evidence hints otherwise (Vrška et al. 2009).

Although the Carpathian Mountains are often seen as the last pristine region of Europe, human beings have been impacting these forests since the Neolithic Age (Vrška et al. 2009). The waves of people arriving in this region in the 13th century, bringing sheep, goats, and cattle with them, led to extensive clear-cutting of forests and heavy grazing of the land (Vrška et al. 2009, WWF 
2016a). One area of forest was spared because it served as protection for the settlements and hilltop pastures (Vrška et al. 2009). The strong presence of grazing animals caused naturally occurring game such as red deer to move away, thereby leading natural predator populations to decrease; firs were advantaged over beech as people and animals were removing the layer of plant litter from the forest floor that had previously served as a barrier for the growth of firs. It was only in the late 19th century that this fir-dominant ecosystem began to shift; forest reserves began to be implemented, plant litter became undisturbed, and grazing was ceased, leading game species to return (Vrška et al. 2009). Because these reserves did not occupy large areas, favorable conditions for the beech were connected with a decrease in human pressure. The creation of a reserve has also resulted in the provision of a large habitat for natural predators that would otherwise be severely threatened (Commarmot and Hamor 2005, Vrška et al. 2009).

The European beech is valued for its ecological, economic, and cultural importance. In 1995, Paule claimed that "the European beech [...] is at present considered the most economically important broadleaf tree species in Europe" (161). This species appears to have sustained the charcoal industry in the ECBR over the past 30 years, yet we were unable to find literature explicitly discussing whether the harvesting of beech tries for charcoal production was being conducted sustainably. The importance of common beech has been reiterated numerous times (Gomory et al. 2003, Commarmot et al. 2013). Not only is it economically important, but it also represents approximately $10 \%$ of European forests (Paule 1995), with some trees being more than 360 years old and with great potential value for properly managed forests to have superior biodiversity outcomes (Brunet et al. 2010).

One study found evidence pointing toward beech forests being in fairly good condition within the region. The Uholka-Shyrokyi Luh project (2013) completed an inventory of 10,000 ha within the largest of beech forests in Europe: the Uholka-Shyrokyi Luh massif, which is located in the Carpathian Biosphere Reserve located near the Ukraine-Romanian border. Although not conducted in the ECBR, their study serves as a useful signal for the state of beech forests in a different part of the Carpathians. The results of the inventory pointed toward "typical features of old growth forests shaped by small-scale disturbances" (Commarmot et al. 2013:6). These results fit within the theory of cyclical rotations between fir and beech believed to be customary to the area. They also noted traces of human presence, such as paths and roads, timber cutting, livestock grazing, and waste, at $19 \%$ of the sites sampled, which they explained were primarily in the buffer zone of the protected area (Commarmot et al. 2013). The study demonstrated that introduced and/or invasive plants do not appear to be a threat in that particular region. As the authors explain, "Apart from a few Norway spruce trees planted beside huts, all species found are of natural origin" (Commarmot et al. 2013:47).

On the other hand, a Ukrainian study found that forest cover change was widespread from 1988 to 2007 in the Ukrainian Carpathians (Kuemmerle et al. 2009). In particular, it appears that unsustainable forest use, which had been widespread during socialist times, has in fact not ceased in this part of Ukraine, leading to forest fragmentation and the loss of older forests (Kuemmerle et al. 2009). To this effect, Kuemmerle et al. state,
"We found forest cover increase in peripheral areas, forest loss in the interior Carpathians, and increased logging in remote areas" (2009:1). Landsat technology enabled these novel findings, results that differ from those stated in the national statistics databases. Secondary succession of forests has tended to occur on the Slovak and Polish sides as a result of the abandonment of agricultural practices (Z. Niewiadomski, 2003, personal communication).

Dead wood in beech forests plays an instrumental role in providing habitat for wood-dwelling animals, fungi, mosses, and lichens (Christensen et al. 2004, 2005, Commarmot et al. 2013). It also serves as a structural indicator when measuring habitat quality (Christensen et al. 2005). One study spanning across 86 beech forest reserves throughout Europe found that "more dead wood was found in montane (rather than lowland/submontane) reserves, longer-established reserves (time since designation) and reserves with higher volumes of living wood" (Christensen et al. 2005:267). The presence of varied and substantial amounts of decomposing wood has important implications for wooddependent organisms. The results of Christensen et al. (2005) could be used to presume that the ECBR, being primarily mountainous and fairly well established, has substantial quantities of dead wood consequently leading to more biodiverse forest ecosystems. If this holds true, the biomass of both live and dead wood serves as a proxy for the effectiveness of the ECBR in protecting forest resources.

A useful tool to measure the ECBR's success is the CPAMETT database (WWF and World Bank 2008, Papp 2011). This webbased tool provides a database on protected area performance based on extensive forms completed by park managers and administrators (Papp 2011). PNP in Slovakia only had one response in CPAMETT, whereas Uzhanskyi National Nature Park (UNNP) in Ukraine had 24. This database is created on a volunteer basis, and differences in response rates could be because of a number of factors, including limited capacity in some protected areas compared with others. Although not flawless, this new database provides a good overview of current threats to 2 of the protected areas within this TBR (Appendix 1, Table A1.1). Based on the 53 types of threats contained within this database, the most significant for both PNP and UNNP are as follows: (1) hunting, killing, and collecting terrestrial animals; (2) logging and wood harvesting; (3) erosion and siltation; (4) temperature extremes; (5) changes in species behavior; and (6) loss of cultural links/traditional ecological management/management practices (WWF and World Bank 2008). Although the majority of the land protected under PNP and UNNP is forest (Table 1), significant parts of the BR are agricultural lands, dedicated mostly to crops for fodder (Guziova 1996). There exists to this day community and privately owned village plots, dedicated to growing wheat, rye, barley, oats, and the traditional crop, buckwheat (Guziova 1996). These agricultural enterprises were on the decline in the late 1990s (Guziova 1996).

Many political and socioeconomic changes have occurred in the past two decades as socialist states have transitioned to market economies (Kuemmerle et al. 2007). Some studies found that harvesting of forest resources increased at the very start of this transition (early 1990s), yet protected areas, especially in Poland and in Slovakia, led to a noticeable drop in harvesting rates (Kuemmerle et al. 2007). This demonstrates the close link between 
forest disturbance and socioeconomic conditions. Studies in the nearby Carpathian Biosphere Reserve have speculated that "factors impacting on the region include the decollectivization of agriculture and forestry, high unemployment rates and work migration, inflation and global developments such as climate change" (Geyer et al. 2009:6). Further, the integration of local groups in decision making has been deficient in that park, causing the reserve to be unpopular (Geyer et al. 2009).

\section{DISCUSSION}

Although the creation of the ECBR has brought national and international actors together in the spirit of collaboration, this has at times excluded some actors, such as remote villages behind, akin to what has happened in neighboring parks (Fall 2006, Geyer et al. 2009). Capacity and funding for park management has gradually decreased, and the will to cooperate among important actors has fluctuated over time, often becoming absent. Deforestation, hunting, erosion, temperature extremes, changes in species behavior, and loss of cultural links were noted to be the most significant threats to the ECBR. For the most part, ecosystems have been safeguarded, but improvement to livelihoods, through employment opportunities and sustainable development has been deficient. Information regarding the ecological characteristics of the ECBR tended to be more available than for social/cultural outcomes of the reserve. The lack of available literature represents a limitation of our study. The use of the SES framework is helpful in analyzing the successes and challenges facing the ECBR today and is well suited to be merged with the International Union for conservation of Nature and Natural Resources (IUCN)/World Commission on Protected Areas (WCPA) framework for assessing management effectiveness of protected areas. Careful attention must be given to the loss of cultural links, traditional knowledge, and ecological attributes to ensure this BR fulfills its role as a model region for sustainable development.

Many of the challenges facing the ECBR are shared by other TBRs worldwide. Social and economic concerns tend to be prioritized over nature conservation in many countries, and this gets reflected in funding allocations. Meager or nonexistent budgets result in an inability to implement best conservation practices, maintain basic operations and staff, and/or embrace new technologies (ECBC 2004). This trend is evident in the ECBR, particularly regarding the lack of operational funding and management capacity, and appears to be so in other protected areas around the world (Singh 1999, Bruner et al. 2004, Emerton et al. 2006). The BR designation does not appear to have led to increased financing or policy support in any of the three countries.

Balancing development needs without compromising ecosystem health remains the most significant challenge of our time. The low to medium recorded levels of residential and commercial developments, energy production and mining, and transportation and service corridors within the ECBR are encouraging when assessing ecosystem conservation. The evidence pointing toward shifting states of the primeval beech forests as a result of human management (Vrška et al. 2009, WWF 2016a), as well as evidence of climate change in the ECBR (Dittmar et al. 2003), demonstrates that these ecosystems are inherently connected to anthropogenic activities and should thus be treated accordingly, rather than perceived as pristine or untouched. Similar development threats have been found to exist in other TBRs, such as the Bialowieza National Park and Biosphere Reserve between Belarus and Poland (Agrawal 2000), and for protected areas in general, as in the Great Barrier Reef Marine Park (Evans et al. 2014).

Managing a TBR as one coherent unit is a tremendous challenge when taking into account different political agendas, national and foreign policy, ecological and economic context, and cultural values. This was highlighted in the case of the ECBR where transboundary cooperation had to overcome deeply rooted hostility as a result of historical events and find a way to achieve a unified cooperative result using three different political management and support systems. The loss of cultural links is concerning, especially because both the Carpathian Convention (2003) and the MAB program's goals are to strengthen local economies, communities, cultural heritage, and the conservation of natural ecosystems (Carpathian Convention 2003, German MAB National Committee 2005, Broggiato et al. 2007a, b). This echoes similar challenges to support local culture and community and view the TBR as an SES, as also seen in the Delta of the Senegal River TBR between Senegal and Mauritania (Vasilijević et al. 2015).

Finding experts to effectively manage and provide leadership for the ECBR over time and through political turmoil was another challenge, as witnessed in many specific transboundary initiatives such as the Dinaric Arc (Vasilijević et al. 2015), as well as with respect to security concerns in TBRs in general (Braack et al. 2006). The sheer size and remoteness of the ECBR adds another layer of complexity. To this effect, Niewiadomski (2011:28) says:

This is also why direct personal contacts between the administrations of two adjacent parks [...] are scarce, despite a short aerial distance of $26 \mathrm{~km}$ between headquarters [...] visiting the partner park required driving a distance of $348 \mathrm{~km}$ and passing through crowded border crossings at the state borders of three countries and being subjected to numerous police and border guard control points, amounting to a full day trip in each direction.

This is compounded by restricted access because of visa requirements and poorly maintained roads. Size is most likely a significant factor in the W Region, the first TBR in Africa, which spans across 3,504,648 ha, or the intercontinental BR of the Mediterranean totaling 894,134 ha (UNESCO 2016a). All of these factors may explain why there are only 16 TBRs worldwide today: 12 in Europe, 2 in Africa, 1 in Latin America, and 1 intercontinental.

This review of the successes and challenges of the ECBR highlights several key factors necessary for the proper implementation of a TBR: (1) A common vision and framework along with common priorities must be identified to guide efforts. (2) A leadership structure must be developed. (3) Joint actions that can be undertaken must be outlined, agreed on, and incorporated into a time line and/or action plan. (4) Affected parties must be consulted and integrated in the decision-making process. (5) A robust budget must be in place to cover operational costs and ensure the TBR's mandate is met (Niewiadomski 2011). These insights align with lessons learned from other TBRs, such 
as the Delta of the Senegal River TBR mentioned previously, which still struggles to achieve sustainable management and social-ecological resilience (Vasilijević et al. 2015), or the Vosges du Nord/Pfälzerwald TBR of France and Germany, which has achieved great successes but remains fragile with respect to sustainability (Stein 2008).

One challenge in this particular case is that much of the literature on the ECBR is dated, and it appears that communications around the reserve have significantly decreased in the past several years. Niewiadomski confirmed that the literature on the ECBR, in particular that which has been published in English, has always been quite sparse. This is particularly true for documentation on social conditions in/around the reserve, as with any literature later than 2006 (Z. Niewiadomski, 2014, personal communication). This gap in the literature is because of political turbulence in Poland between 2005 and 2007 (Z. Niewiadomski, 2014, personal communication). A similar gap in current literature may very well arise as a result of the current political turmoil in Ukraine, leading up to and following the 2014 revolution (Wilson 2014). We thus recognize that our results paint an incomplete picture of the ECBR, one that is lacking the latest advances or shortcomings of the reserve as a result of the current political climate. It should also be noted that there remain insufficient data within the literature to properly address the impact of the ECBR on human livelihoods. Future research should focus on monitoring the ecological and social outcomes of the reserve and how these have changed over the past decade.

Monitoring the progress and effectiveness of a protected area and open publication of results is key to its success. In 2006, the IUCN/ WCPA published Evaluating Effectiveness: A Framework for Assessing Management Effectiveness of Protected Areas (Hockings et al. 2006). Papp (2011) explains that the core elements that must be considered according to this framework include context, planning, inputs, processes, outputs, and outcomes. Measuring and assessing outcomes in a complex SES like a TBR requires tools to help with the analysis. A BR is much more than a protected area. We found that Ostrom's general framework for analyzing sustainability of SESs (Fig. 2) goes hand in hand with the framework for assessing management effectiveness of protected areas spearheaded by IUCN and WCPA. Tracking management effectiveness is just one of many aspects that are important when considering the sustainability of an SES, yet an important one. Assessing the successes and failures of the ECBR using the framework of resources, governance, external influences, and actors proved to be helpful in providing the context of this TBR and assessing its progress and shortcomings to date.

\section{CONCLUSION}

We set out to analyze whether the ECBR has been effective at safeguarding its natural ecosystems while improving human livelihoods. Every component of the ECBR is dissimilar to the other: the parks within it, people, languages, culture, history, demographic trends, economic activity, farming practices, ecological and geographic context, military context, and driving values (Niewiadomski 2006, Stein et al. 2006). This has unquestionably presented a formidable challenge and unique opportunity. However, competing and opposing values are present everywhere and are at the core of the sustainability challenge. As Hodge (1997:5) explained, "A conceptual approach to assessing progress toward sustainability is founded on a value set that insists on parallel care and respect for people and the ecosystem together." The continued existence of the ECBR after nearly two decades despite lack of funding and stresses is a success of its own. The ECBR's greatest strength lies in three countries, each using its own legislation, practices, and prioritizes to ensure social, environmental, and economic benefits to all. It is the strengthening of this shared value set and actions that align with it that will preserve the ecosystems of the Eastern Carpathians and enable the ECBR to be a model for the MAB program. Partners collaborating with a common vision, an understanding of mutual benefits, and a respect for each other's differences is undeniably the most important factor for achieving the BR's mandate.

Fig. 2. A general framework for analyzing social-ecological systems.

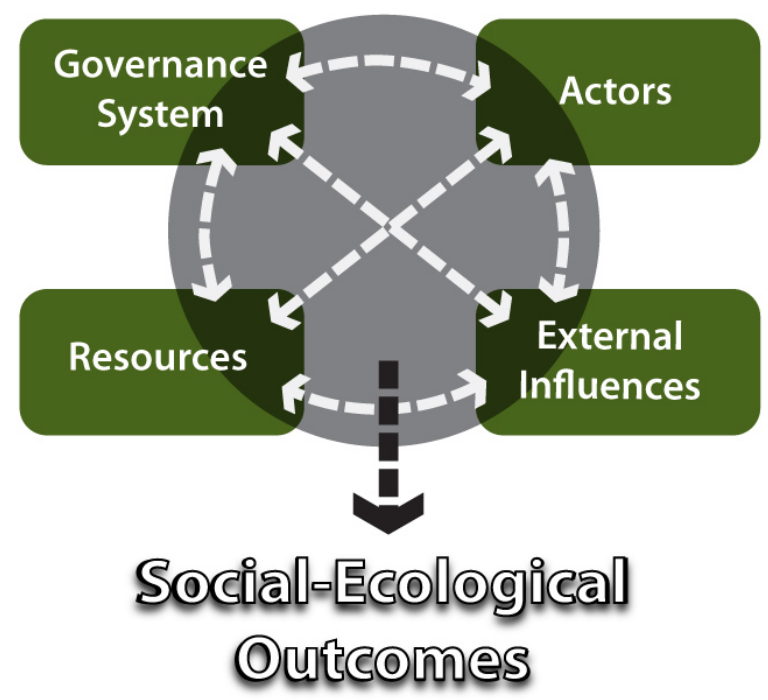

Responses to this article can be read online at: http://www.ecologyandsociety.org/issues/responses. $\mathrm{php} / 8669$

\section{Acknowledgments:}

We gratefully acknowledge Zbigniew Niewiadomski whose significant contribution through detailed, helpful comments and sharing of gray literature made this manuscript possible. We extend our gratitude to Maja Vasilijević, who provided the introduction to Mr. Niewiadomski. Thank you to Natalie Ban for continually providing encouragement, offering constructive feedback in the early stages of the manuscript, and introducing us coauthors to each other! A special thanks to Fred Roots, a longtime mentor, who was the first to introduce me to the East Carpathians Biosphere Reserve and who provided invaluable feedback along the way. 


\section{LITERATURE CITED}

Adamcík, S., M. Christensen, J. Heilmann-Clausen, and R. Walleyn. 2007. Fungal diversity in the Poloniny National Park with emphasis on indicator species of conservation value of beech forests in Europe. Czech Mycology 59(1):67-81.

Agrawal, A. 2000. Adaptive management in transboundary protected areas: the Bialowieza National Park and Biosphere Reserve as a case study. Environmental Conservation 27 (4):326-333. http://dx.doi.org/10.1017/S0376892900000370

Ali, S. H., editor. 2007. Peace parks: conservation and conflict resolution. MIT Press, Cambridge, Massachusetts, USA.

Austrian Man and the Biosphere (MAB) Committee. 2011. Biosphere reserves in the mountains of the world: excellence in the clouds? Austrian Academy of Sciences Press, Vienna, Austria.

Batisse, M. 1997. Biosphere reserves: a challenge for biodiversity conservation \& regional development. Environment: Science and Policy for Sustainable Development 39(5):6-33. http://dx.doi. org/10.1080/00139159709603644

Beckmann, A. 2013. The Carpathian Convention at 10: on the map, but much left to do. 22 May. WWF, Gland, Switzerland. [online] URL: http://wwf.panda.org/?208722/The-CarpathianConvention-at-10-On-the-map-but-much-left-to-do

Bihun, Y. M., W. S. Keeton, O. Stankiewicz, and M. Ceroni. 2008. Transboundary protected areas cooperation in the East Carpathian and Carpathian Biosphere Reserves. Final Report. World Wide Fund for Nature (WWF) Austria, Vienna, Austria.

Braack, L., T. Sandwith, D. Peddle, and T. Petermann. 2006. Security considerations in the planning and management of transboundary conservation areas. International Union for conservation of Nature and Natural Resources (IUCN), Gland, Switzerland.

Breymeyer, A. 1997. Biosphere reserves in Poland. Agencja Reklamowo, Warsaw, Poland.

Breymeyer, A. 2007. Wetlands and waters on European eastern border: is this the opportunity for the application of ecohydrology in transborder biosphere reserves? Ecohydrology \& Hydrobiology 7(2):135-146. http://dx.doi.org/10.1016/s1642-3593(07)70179-9

Breymeyer, A., and P. Dabrowski. 2000. Biosphere reserves on borders. United Nations Educational, Scientific and Cultural Organization (UNESCO), Man and the Biosphere (MAB) Committee of Poland, Warsaw, Poland.

Broggiato, A., T. B. Filipova, L. Cetara, J. Church, G. Luciani, C. Monnier, and P. Sandei. 2007a. Handbook on the Carpathian Convention. The Regional Environmental Center for Central and Eastern Europe and the European Academy Bolzano, Szentendre, Hungary.

Broggiato, A., T. B. Filipova, G. Luciani, M. Markus-Johansson, C. Monnier, D. Romanescu, and S. Stec. 2007b. A heightened perspective regional assessment of the policy, legislative and institutional frameworks implementing the Carpathian Convention. The Regional Environmental Center for Central and Eastern Europe and the European Academy Bolzano, Szentendre, Hungary.
Bruner, A. G., R. E. Gullison, and A. Balmford. 2004. Financial costs and shortfalls of managing and expanding protected-area systems in developing countries. BioScience 54(12):1119-1126. http://dx.doi.org/10.1641/0006-3568(2004)054[1119:fcasom]2.0.co;2

Brunet, J., Ö. Fritz, and G. Richnau. 2010. Biodiversity in European beech forests - a review with recommendations for sustainable forest management. Ecological Bulletins 53:77-94.

Büscher, B. 2013. Transforming the frontier: peace parks and the politics of neoliberal conservation in southern Africa. Duke University Press, Durham, North Carolina, USA. http://dx.doi. org/10.1215/9780822399087

Carpathian Convention. [date unknown]. Conference of the Parties. United Nations Environment Programme (UNEP) Vienna Office, Secretariat of the Carpathian Convention, Vienna, Austria. [online] URL: http://www.carpathianconvention.org/ conference-of-the-parties-50.html

Carpathian Convention. [date unknown]. The convention. United Nations Environment Programme (UNEP) Vienna Office, Secretariat of the Carpathian Convention, Vienna, Austria. [online] URL: http://www.carpathianconvention.org/the-convention-17. $\underline{\text { html }}$

Carpathian Convention. 2003. Framework convention on the protection and sustainable development of the Carpathians. Carpathian Convention, Kyiv, Ukraine. [online] URL: http:// www.carpathianconvention.org/tl_files/carpathiancon/Downloads/ $01 \%$ 20The $\% 20$ Convention/1.1.1.1 CarpathianConvention.pdf

Christensen, M., K. Hahn, E. P. Mountford, P. Ódor, T. Standovár, D. Rozenbergar, J. Diaci, S. Wijdeven, P. Meyer, S. Winter, and T. Vrska. 2005. Dead wood in European beech (Fagus sylvatica) forest reserves. Forest Ecology and Management 210 (1-3):267-282. http://dx.doi.org/10.1016/j.foreco.2005.02.032

Christensen, M., J. Heilmann-Clausen, R. Walleyn, and S. Adamcík. 2004. Wood-inhabiting fungi as indicators of natural value in European beech forests. Pages 229-237 in M. Marchetti, editor. Monitoring and indicators of forest biodiversity in Europe, from ideas to operationality. European Forest Institute (EFI) Proceedings No. 51. EFI, Joensuu, Finland.

Commarmot, B., U. Brändli, F. Hamor, and V. Lavny. 2013. Inventory of the largest primeval beech forest in Europe. A SwissUkrainian scientific adventure. Swiss Federal Institute for Forest, Snow and Landscape Research WSL, Birmensdorf, Switzerland; Ukrainian National Forestry University, L'viv Carpathian Biosphere Reserve, Rakhiv, Ukraine.

Commarmot, B., and F. D. Hamor, editors. 2005. Natural forests in the temperate zone of Europe - values and utilisation. Conference 13-17 October 2003, Mukachevo, Ukraine: proceedings. Swiss Federal Research Institute WSL, Birmensdorf, Switzerland; Carpathian Biosphere Reserve, Rakhiv, Ukraine.

Conca, K., and G. D. Dabelko, editors. 2002. Environmental peacemaking. Woodrow Wilson Center Press, Washington, D.C., USA.

Cox, M. 2014. Understanding large social-ecological systems: introducing the SESMAD project. International Journal of the Commons 8(2):265-276. http://dx.doi.org/10.18352/ijc.406 
Denisiuk, Z., S. Stoyko, and J. Terray. 1997. Experience in crossborder cooperation for national park and protected areas in central Europe. Pages 145-150 in J. G. Nelson and R. Serafin, editors. National parks and protected areas: keystones to conservation and sustainable development. Springer, Berlin, Germany. http://dx.doi.org/10.1007/978-3-642-60907-7_13

Dittmar, C., W. Zech, and W. Elling. 2003. Growth variations of common beech (Fagus sylvatica L.) under different climatic and environmental conditions in Europe - a dendroecological study. Forest Ecology and Management 173(1):63-78. http://dx.doi. org/10.1016/S0378-1127(01)00816-7

Dovčiak, M. 2002. Population dynamics of the endangered English yew (Taxus baccata L.) and its management implications for biosphere reserves of the western Carpathians. Man and the Biosphere (MAB) Secretariat, Division of Ecological Sciences, United Nations Educational, Scientific and Cultural Organization (UNESCO), Paris, France.

Durak, T. 2010. Long-term trends in vegetation changes of managed versus unmanaged eastern Carpathian beech forests. Forest Ecology and Management 260(8):1333-1344. http://dx.doi. org/10.1016/j.foreco.2010.07.026

Elbakidze, M., and P. Angelstam. 2007. Implementing sustainable forest management in Ukraine's Carpathian Mountains: the role of traditional village systems. Forest Ecology and Management 249(1-2):28-38. http://dx.doi.org/10.1016/j.foreco.2007.04.003

Emerton, L., J. Bishop, and L. Thomas. 2006. Sustainable financing of protected areas: a global review of challenges and options. International Union for conservation of Nature and Natural Resources (IUCN), Gland, Switzerland.

EuroMAB. 1993. Access: a directory of contacts, environmental data bases, and scientific infrastructure on 175 biosphere reserves in 32 countries. National Technical Information Service, Springfield, Virginia, USA. [online] URL: http://files.eric.ed.gov/ fulltext/ED406133.pdf

EUROPARC. 2015. Discover our transboundary parks. EUROPARC Federation, Regensburg, Germany. [online] URL: http://www.europarc.org/nature/transboundary-parks/discover-ourtransboundary-areas/

Evans, L. S., N. C. Ban, M. Schoon, and M. Nenadovic. 2014. Keeping the 'Great' in the Great Barrier Reef: large-scale governance of the Great Barrier Reef Marine Park. International Journal of the Commons 8(2):396-427. http://dx.doi.org/10.18352/ ijc. 405

Fall, J. J. 1999. Transboundary biosphere reserves: a new framework for cooperation. Environmental Conservation 26 (4):252-255. http://dx.doi.org/10.1017/s0376892999000363

Fall, J. J. 2003. Planning protected areas across boundaries: new paradigms and old ghosts. Journal of Sustainable Forestry 17 (1-2):81-102. http://dx.doi.org/10.1300/j091v17n01_06

Fall, J. 2006. Designing framework conventions to promote and support transboundary protected areas: theory and practice from the Carpathian Convention. Pages 101-117 in G. Tamburelli, editor. Biodiversity conservation and protected areas: the Italian and Ukrainian legislation. Series Istituto di Studi Giuridici Internazionali, 7. Giuffré Editore, Milan, Italy.
Fleischman, F. D., N. C. Ban, L. S. Evans, G. Epstein, G. GarciaLopez, and S. Villamayor-Tomas. 2014a. Governing large-scale social-ecological systems: lessons from five cases. International Journal of the Commons 8(2):428-456. http://dx.doi.org/10.18352/ ijc.416

Fleischman, F. D., B. Loken, G. A. Garcia-Lopez, and S. Villamayor-Tomas. 2014b. Evaluating the utility of common-pool resource theory for understanding forest governance and outcomes in Indonesia between 1965 and 2012. International Journal of the Commons 8(2):304-336. http://dx.doi.org/10.18352/ ijc. 409

Foundation for Eastern Carpathians Biodiversity Conservation (ECBC). [date unknown]. Transboundary cooperation in the Eastern Carpathians. Foundation brochure. ECBC, Ustrzyki Górne, Poland.

Foundation for Eastern Carpathians Biodiversity Conservation (ECBC). 2004. Challenges and opportunities for biodiversity conservation in the East Carpathians. Foundation brochure. ECBC, Ustrzyki Górne, Poland.

German Man and the Biosphere (MAB) National Committee, editor. 2005. Full of life: UNESCO biosphere reserves - model regions for sustainable development. Springer-Verlag, Berlin, Germany.

Geyer, J., F. D. Hamor, and P. L. Ibisch. 2009. Carpathian biosphere reserve (Ukraine): towards participatory management. eco.mont: Journal on Protected Mountain Areas Research 1 (2):5-12. http://dx.doi.org/10.1553/ecomont2s5

Gomory, D., L. Paule, I. Shvadchak, F. Popescu, M. Sulkowska, V. Hynek, and R. Longauer. 2003. Spatial patterns of the genetic differentiation in European beech (Fagus sylvatica L.) at allozyme loci in the Carpathians and the adjacent regions. Silvae Genetica 52(2):78-83.

Guziova, Z. 1996. Vychodne Karpaty/East Carpathian Biosphere Reserve. Pages 135-140 in A. Breymeyer and R. Noble, editors. Biodiversity conservation in transboundary protected areas. National Academies Press, Washington, D.C., USA.

Hanks, J. 2003. Transfrontier conservation areas (TFCAs) in southern Africa: their role in conserving biodiversity, socioeconomic development and promoting a culture of peace. Journal of Sustainable Forestry 17(1-2):127-148. http://dx.doi. org/10.1300/j091v17n01 08

Harrison, S., and E. Bruna. 1999. Habitat fragmentation and large-scale conservation: what do we know for sure? Ecography 22(3):225-232. http://dx.doi.org/10.1111/j.1600-0587.1999.tb00496. $\underline{x}$

Hockings, M., S. Stolton, F. Leverington, N. Dudley, and J. Courrau. 2006. Evaluating effectiveness: a framework for assessing the management of protected areas. Second edition. International Union for conservation of Nature and Natural Resources (IUCN), Gland, Switzerland.

Hodge, T. 1997. Toward a conceptual framework for assessing progress toward sustainability. Social Indicators Research 40 (1):5-98. http://dx.doi.org/10.1023/A:1006847209030 
Jaworski, A., Z. Kolodziej, and K. Porada. 2002. Structure and dynamics of stands of primeval character in selected areas of the Bieszczady National Park. Journal of Forest Science 48 (5):185-201.

Karivalo, L. 2009. EUROPARC transboundary cooperation transboundary parks - following nature's design process. Workshop B7 working across borders. EUROPARC 2009 Conference (Strömstad, Sweden). EUROPARC Federation, Regensburg, Germany.

Kuemmerle, T., O. Chaskovskyy, J. Knorn, V. C. Radeloff, I. Kruhlov, W. S. Keeton, and P. Hostert. 2009. Forest cover change and illegal logging in the Ukrainian Carpathians in the transition period from 1988 to 2007. Remote Sensing of Environment 113 (6):1194-1207. http://dx.doi.org/10.1016/j.rse.2009.02.006

Kuemmerle, T., P. Hostert, V. C. Radeloff, K. Perzanowski, and I. Kruhlov. 2007. Post-socialist forest disturbance in the Carpathian border region of Poland, Slovakia, and Ukraine. Ecological Applications 17(5):1279-1295. http://dx.doi. org/10.1890/06-1661.1

Kuemmerle, T., V. C. Radeloff, K. Perzanowski, and P. Hostert. 2006. Cross-border comparison of land cover and landscape pattern in Eastern Europe using a hybrid classification technique. Remote Sensing of Environment 103(4):449-464. http://dx.doi. org/10.1016/j.rse.2006.04.015

Kukulak, J. 2014. Charcoal in alluvium of mountain streams in the Bieszczady Mountains (Polish Carpathians) as a carrier of information on the local paleoenvironment. Geochronometria 41 (3):294-305. http://dx.doi.org/10.2478/s13386-013-0155-0

López-Hoffman, L., R. G. Varady, K. W. Flessa, and P. Balvanera. 2010. Ecosystem services across borders: a framework for transboundary conservation policy. Frontiers in Ecology and the Environment 8(2):84-91. http://dx.doi.org/10.1890/070216

Man and the Biosphere (MAB). 2007. UNESCO - MAB biosphere reserves directory: biosphere reserve informationEast Carpathians. UNESCO, Paris, France. [online] URL: http:// www.unesco.org/mabdb/br/brdir/directory/biores.asp?code $=$ POL$\underline{\text { SLO-UKR }+01 \& \text { mode }=\text { all }}$

McGinnis, M. D., and E. Ostrom. 2014. Social-ecological system framework: initial changes and continuing challenges. Ecology and Society 19(2):30. http://dx.doi.org/10.5751/ES-06387-190230

Niewiadomski, Z. 2003. Constraints and opportunities for transboundary cooperation in the Eastern Carpathians: towards implementation of the Carpathian Convention. Unpublished report. Project implemented under the United Nations Environment Programme (UNEP)/European Centre for Nature Conservation (ECNC)/International Union for the Conservation of Nature and Natural Resources (IUCN)/Regional Environmental Center for Central and Eastern Europe (REC) "Biodiversity Service Project." Foundation for Eastern Carpathians Biodiversity Conservation, Geneva, Switzerland.

Niewiadomski, Z. 2005. Common working groups in the Eastern Carpathians Biosphere Reserve Activities Report 2004. Foundation for Eastern Carpathians Biodiversity Conservation, Geneva, Switzerland.
Niewiadomski, Z. 2006. The first trilateral UNESCO-MAB Biosphere Reserve 'East Carpathians' (Poland/Slovakia/ Ukraine). Pages 26-35 in R. Stein, P. Heil, and L. Tuček, editors. Proceedings of the 2004 International Conference and Expert Workshop of Transboundary Biosphere Reserves: 'following-up on Seville +5.' Naturpark Pfälzerwald, Lambrecht, Germany; Parc Naturel Régional des Vosges du Nord, La Petite-Pierre, France.

Niewiadomski, Z. 2011. The East Carpathians - the world's first trilateral UNESCO biosphere reserve. Pages 26-30 in $\mathrm{M}$. Vasilijević and T. Pezold, editors. Crossing borders for nature: European examples of transboundary conservation. International Union for Conservation of Nature and Natural Resources (IUCN), Gland, Switzerland.

Ostrom, E. 2009. A general framework for analyzing sustainability of social-ecological systems. Science 325 (5939):419-422. http://dx.doi.org/10.1126/science.1172133

Oszlányi, J., K. Grodzińska, O. Badea, and Y. Shparyk. 2004. Nature conservation in central and eastern Europe with a special emphasis on the Carpathian Mountains. Environmental Pollution 130(1):127-134. http://dx.doi.org/10.1016/j.envpol.2003.10.028

Otýpková, Z., M. Chytrý, L. Tichý, V. Pechanec, J. Jongepier, and O. Hájek. 2011. Floristic diversity patterns in the White Carpathians Biosphere Reserve, Czech Republic. Biologia 66 (2):266-274. http://dx.doi.org/10.2478/s11756-011-0004-7

Papp, C.-R. 2011. Tracking management effectiveness: experiences from two Carpathian biosphere reserves. Pages 112-115 in Austrian MAB Committee, editor. Biosphere reserves in the mountains of the world: excellence in the clouds? Austrian Academy of Sciences Press, Vienna, Austria.

Parties to the Carpathian Convention. 2008. Protocol on conservation and sustainable use of biological and landscape diversity to the framework convention on the protection and sustainable development of the Carpathians. Second Meeting of the Conference of the Parties to the Carpathian Convention (COP2). United Nations Environment Programme (UNEP) Vienna Office, Secretariat of the Carpathian Convention, Vienna, Austria. [online] URL: http://www.carpathianconvention.org/ tl_files/carpathiancon/Downloads/01\%20The $\% 20$ Convention/1.1.2.1\% 20BiodiversityProtocolFinalsigned.pdf

Parties to the Carpathian Convention. 2011a. Protocol on sustainable forest management to the framework convention on the protection and sustainable development of the Carpathians. Third Meeting of the Conference of the Parties to the Carpathian Convention (COP3). United Nations Environment Programme (UNEP) Vienna Office, Secretariat of the Carpathian Convention, Vienna, Austria. [online] URL: http://www. carpathianconvention.org/tl files/carpathiancon/Downloads $/ 03 \%$ 20Meetings $\% 20$ and $\% 20$ Events/COP/2011_COP3 Bratislava/5ProtocolonSustainableForestManagementsigned27may2011.pdf

Parties to the Carpathian Convention. 2011b. Protocol on sustainable tourism to the framework convention on the protection and sustainable development of the Carpathians. Third Meeting of the Conference of the Parties to the Carpathian Convention (COP3). United Nations Environment Programme (UNEP) Vienna Office, Secretariat of the Carpathian Convention, Vienna, Austria. [online] URL: http://www.carpathianconvention.org/ 
tl_files/carpathiancon/Downloads/03\%20Meetings $\% 20$ and $\% 20$ Events/ COP/2011_COP3_Bratislava/6ProtocolonSustainableTourismsigned27May2011.pdf

Parties to the Carpathian Convention. 2014a. Corrigendum strategic action plan for the implementation of the protocol on conservation and sustainable use of biological and landscape diversity (Bucharest, 2008) to the framework convention on the protection and sustainable development of the Carpathians (Kyiv, 2003). UNEP/CC/COP4/DOC7. United Nations Environment Programme (UNEP) Vienna Office, Interim Secretariat of the Carpathian Convention (ISCC), Vienna, Austria. [online] URL: http://www.carpathianconvention.org/tl files/carpathiancon/ Downloads $/ 03 \% 20$ Meetings $\% 20$ and $\% 20$ Events/ COP/2014 COP4 Mikulov/WORKING\%20DOCUMENTS/ DOC7 Biodiversity $\% 20$ Protocol $\% 20$ SAP Corrigendum.pdf

Parties to the Carpathian Convention. 2014b. Protocol on sustainable transport to the framework convention on the protection and sustainable development of the Carpathians. Fourth Meeting of the Conference of the Parties to the Carpathian Convention (COP4). United Nations Environment Programme (UNEP) Vienna Office, Secretariat of the Carpathian Convention, Vienna, Austria. [online] URL: http://www.carpathianconvention.org/ tl files/carpathiancon/Downloads/03\%20Meetings $\% 20$ and $\% 20$ Events/ COP/2014 COP4 Mikulov/Follow\%20Up/Protocol on Sustainable Transport_signed.pdf

Parties to the Carpathian Convention. 2014c. Strategy for sustainable tourism development of the Carpathians. Fourth Meeting of the Conference of the Parties to the Carpathian Convention (COP4). UNEP/CC/COP4/DOC14. United Nations Environment Programme (UNEP) Vienna Office, Secretariat of the Carpathian Convention, Vienna, Austria. [online] URL: http://www.carpathianconvention.org/tl files/carpathiancon/ Downloads $/ 03 \% 20$ Meetings $\% 20$ and $\% 20$ Events/ COP/2014 COP4 Mikulov/WORKING\%20DOCUMENTS/ DOC14 Carpathian $\% 20$ Convention $\% 20$ Sustainable $\% 20$ Tourism $\%$ 20Strategy updated.pdf

Paule, L. 1995. Gene conservation in European beech (Fagus sylvatica L.). Forest Genetics 2(3):161-170.

Perzanowski, K., and W. Olech. 2007. A future for European bison Bison bonasus in the Carpathian ecoregion? Wildlife Biology 13(1):108-112. http://dx.doi.org/10.2981/0909-6396(2007)13[108: AFFEBB]2.0.CO;2

Perzanowski, K., W. Olech, and I. Kozak. 2004. Constraints for re-establishing a meta-population of the European bison in Ukraine. Biological Conservation 120(3):345-353. http://dx.doi. org/10.1016/j.biocon.2004.03.006

Ruzickova, H., L. Halada, S. David, and K. Gerhátová. 1998. Management of meadows in the Biosphere Reserve East Carpathians. Ekológia (Bratislava) 17(3):255-264.

Schoon, M. L. 2012. Building robustness to disturbance: governance in southern African peace parks. Pages 205-236 in M. S. Quinn, L. Broberg, and W. Freimund. Parks, peace, and partnerships: global initiatives in transboundary conservation. University of Calgary Press, Calgary, Alberta, Canada.
Schoon, M. L., and M. E. Cox. 2012. Understanding disturbances and responses in social-ecological systems. Society and Natural Resources 25(2):141-155. http://dx.doi.org/10.1080/08941920.2010.549933

Senn-Irlet, B., J. Heilmann-Clausen, D. Genney, and A. Dahlberg. 2007. Guidance for conservation of macrofungi in Europe. Document prepared for the European Council for Conservation of Fungi (ECCF) within the European Mycological Association (EMA) and the Directorate of Culture and Cultural and Natural Heritage, Council of Europe, Strasbourg, France. [online] URL: http://www.wsl.ch/eccf/Guidance Fungi.pdf

Singh, J. 1999. Study on the development of transboundary natural resource management areas in southern Africa. Global review: lessons learned. Biodiversity Support Program, Washington, D. C., USA.

Sourd, C. 2004. Explaining biosphere reserves. UNESCO, Paris, France.

Štátna ochrana prírody Slovenskej republiky (ŠOP SR). 2010. Poloniny National Park and East Carpathian Biosphere Reserve. ŠOP SR, Banská Bystrica, Slovakia. [online] URL: http://www. sopsr.sk/nppoloniny/en/nature.php

Štátna ochrana prírody Slovenskej republiky (ŠOP SR). 2013. The agreement on the functioning of the International Biosphere Reserve "Eastern Carpathians" and Coordination Council of International Biosphere Reserve "Eastern Carpathians" of 15 November 2013. ŠOP SR, Banská Bystrica, Slovakia. [online] URL: http://www.sopsr.sk/european diploma poloniny/1/ files/10 TRILATERAL nov 2013.pdf

Stein, R. 2008. The Pfalzerwald? Vosges du Nord transboundary biosphere reserve. International Journal of Environment and Sustainable Development 7(2):156-169. http://dx.doi.org/10.1504/ IJESD.2008.018361

Stein, R., P. Heil, and L. Tuček, editors. 2006. Proceedings of the 2004 International Conference and Expert Workshop of Transboundary Biosphere Reserves: 'following-up on Seville +5.' Naturpark Pfälzerwald, Lambrecht, Germany; Parc Naturel Régional des Vosges du Nord, La Petite-Pierre, France. [online] URL: http://www.unesco.org/mab/doc/euromab/doc/Proceedings2004. pdf

Supreme Council of Ukraine. 1995. Law of Ukraine on the status of highland localities in Ukraine of Feb. 15, 1995, no. 56/95-VR. No. 9, article 58 [title translated from the Ukranian]. Supreme Council of Ukraine, Kiev, Ukraine. [online] URL: http://zakon1. rada.gov.ua/laws/show $/ 56 / 95-\%$ D0 $\%$ B2 $\%$ D $1 \% 80$

United Nations Division for Sustainable Development. 1992. Agenda 21: United Nations Conference on Environment \& Development, Rio de Janeiro, Brazil, 3 to 14 June 1992. United Nations Division for Sustainable Development, New York, New York, USA. [online] URL: https://sustainabledevelopment.un. org/content/documents/Agenda21.pdf

United Nations Educational, Scientific and Cultural Organization (UNESCO). 1996. Biosphere reserves: the Seville strategy and the statutory framework of the World Network. UNESCO, Paris, France. 
United Nations Educational, Scientific and Cultural Organization (UNESCO). 2001. Seville +5: international meeting of experts-proceedings, comptes rendus, actas (Pamplona, Spain, 23-27 October 2000). Man and the Biosphere (MAB) Report Series No. 69. UNESCO, Paris, France.

United Nations Educational, Scientific and Cultural Organization (UNESCO). 2003. Five transboundary biosphere reserves in Europe. Biosphere Reserves Technical Notes. UNESCO, Paris, France.

United Nations Educational, Scientific and Cultural Organization (UNESCO). 2016a. Ecological sciences for sustainable development: World Network of Biosphere Reserves (WNBR). UNESCO, Paris, France. [online] URL: http://www. unesco.org/new/en/natural-sciences/environment/ecological-sciences/ biosphere-reserves/world-network-wnbr/

United Nations Educational, Scientific and Cultural Organization (UNESCO). 2016b. Lima Action Plan for UNESCO's Man and the Biosphere (MAB) programme and its World Network of Biosphere Reserves (2016-2025). Endorsed by the 4th World Congress of Biosphere Reserves on 17 March 2016 and adopted by the 28th MAB ICC on 19 March 2016, Lima, Peru. UNESCO, Paris, France.

Uvarov, A. V. 2000. Effects of smoke emissions from a charcoal kiln on the functioning of forest soil systems: a microcosm study. Environmental Monitoring and Assessment 60:337-357. http://dx. doi.org/10.1023/A:1006115104675

Van Aarde, R. J., and T. P. Jackson. 2007. Megaparks for metapopulations: addressing the causes of locally high elephant numbers in southern Africa. Biological Conservation 134 (3):289-297. http://dx.doi.org/10.1016/j.biocon.2006.08.027

Vasilijević, M., K. Zunckel, M. McKinney, B. Erg, M. Schoon, and T. Rosen Michel. 2015. Transboundary conservation: a systematic and integrated approach. Best Practice Protected Area Guidelines Series No. 23. International Union for Conservation of Nature and Natural Resources (IUCN), Gland, Switzerland.

Villamayor-Tomas, S., F. D. Fleischman, I. P. Ibarra, A. Thiel, and F. van Laerhoven. 2014. From Sandoz to salmon: conceptualizing resource and institutional dynamics in the Rhine watershed through the SES framework. International Journal of the Commons 8(2):361-395. http://doi.org/10.18352/ijc.411 http:// dx.doi.org/10.18352/ijc.411

Vrška, T., D. Adam, L. Hort, T. Kolář, and D. Janík. 2009. European beech (Fagus sylvatica L.) and silver fir (Abies alba Mill.) rotation in the Carpathians - a developmental cycle or a linear trend induced by man? Forest Ecology and Management 258(4):347-356. http://dx.doi.org/10.1016/j.foreco.2009.03.007

Wilson, A. 2014. Ukraine crisis: what it means for the West. Yale University Press, New Haven, Connecticut, USA.

World Wide Fund for Nature (WWF). 2001. The status of the Carpathians: a report developed as a part of the Carpathian Ecoregion Initiative. Danube-Carpathian Programme, WWF International, Vienna, Austria.

World Wide Fund for Nature (WWF). 2016a. The Carpathians. WWF, Gland, Switzerland. [online] URL: http://wwf.panda.org/ what we do/where we work/black sea basin/danube carpathian/ our_solutions/wilderness_protected_areas/carpathians/

World Wide Fund for Nature (WWF). 2016b. The green heart of Europe: the Danube-Carpathian region. WWF, Gland, Switzerland. [online] URL: http://wwf.panda.org/what we do/ where we work/black sea basin/danube carpathian/

blue river green $\mathrm{mtn} /$

World Wide Fund for Nature (WWF) and World Bank. 2008. Carpathian protected area management effectiveness tracking tool. WWF, Gland, Switzerland. 


\section{Appendix 1}

Table A1.1. Threats identified by park administrators and managers in PNP and UNNP

\begin{tabular}{|c|c|c|c|}
\hline Threat & $\begin{array}{c}\text { Poloniny National Park } \\
\text { (1) }\end{array}$ & $\begin{array}{c}\text { Uzhanskiy National } \\
\text { Nature Park (24) }\end{array}$ & Notes \\
\hline \multicolumn{4}{|c|}{ Residential and commercial development within the protected area } \\
\hline Housing and settlement & Low & Low & \\
\hline $\begin{array}{l}\text { Commercial and industrial } \\
\text { areas }\end{array}$ & Low & Low & \\
\hline $\begin{array}{l}\text { Tourism and recreation } \\
\text { infrastructure }\end{array}$ & Low & Medium & \\
\hline \multicolumn{4}{|c|}{ Agriculture and aquaculture within the protected area } \\
\hline $\begin{array}{l}\text { Annual and perennial non- } \\
\text { timber crop cultivation }\end{array}$ & Low & Low & \\
\hline Wood and pulp plantations & $\mathrm{N} / \mathrm{A}$ & $\mathrm{N} / \mathrm{A}$ & \\
\hline Livestock farming and grazing & $\mathrm{N} / \mathrm{A}$ & Medium & \\
\hline $\begin{array}{l}\text { Marine and freshwater } \\
\text { aquaculture }\end{array}$ & $\mathrm{N} / \mathrm{A}$ & $\mathrm{N} / \mathrm{A}$ & \\
\hline \multicolumn{4}{|c|}{ Energy production and mining within the protected area } \\
\hline Oil and gas drilling & N/A & Low & \\
\hline Mining and gas quarrying & $\mathrm{N} / \mathrm{A}$ & Medium & \\
\hline Hydropower dams & Low & $\mathrm{N} / \mathrm{A}$ & \\
\hline Wind farms & $\mathrm{N} / \mathrm{A}$ & $\mathrm{N} / \mathrm{A}$ & \\
\hline Other & Medium & $\mathrm{N} / \mathrm{A}$ & \\
\hline \multicolumn{4}{|c|}{ Transportation and service corridors within the protected area } \\
\hline Roads and railroads & Low & Medium & \\
\hline Utility and service lines & Low & Medium & \\
\hline Shipping lanes and canals & $\mathrm{N} / \mathrm{A}$ & $\mathrm{N} / \mathrm{A}$ & \\
\hline Flight paths & N/A & Low & \\
\hline \multicolumn{4}{|c|}{ Biological resource use and harm within the protected area } \\
\hline $\begin{array}{l}\text { Hunting, killing and collecting } \\
\text { terrestrial animals }\end{array}$ & Medium & High & Common threat \\
\hline $\begin{array}{l}\text { Gathering terrestrial plants or } \\
\text { plant products }\end{array}$ & Low & Medium & \\
\hline Logging and wood harvesting & High & Medium & Common threat \\
\hline $\begin{array}{l}\text { Fishing, killing and harvesting } \\
\text { aquatic resources }\end{array}$ & Low & Medium & \\
\hline \multicolumn{4}{|c|}{ Human intrusions and disturbance within the protected area } \\
\hline $\begin{array}{l}\text { Recreational activities and } \\
\text { tourism }\end{array}$ & Low & Low & \\
\hline $\begin{array}{l}\text { Ski infrastructure, } \\
\text { developments }\end{array}$ & Low & Low & \\
\hline $\begin{array}{l}\text { War, civil unrest, military } \\
\text { exercises }\end{array}$ & N/A & N/A & \\
\hline Research \& education & Low & Low & \\
\hline Activities of PA managers & Medium & Low & \\
\hline $\begin{array}{l}\text { Deliberate vandalism, } \\
\text { destructive activities }\end{array}$ & Low & Medium & \\
\hline \multicolumn{4}{|c|}{ Natural system modifications } \\
\hline Fire and fire suppression & Low & Low & \\
\hline $\begin{array}{l}\text { Dams, hydrological } \\
\text { modification and water } \\
\text { management/use }\end{array}$ & Medium & Low & \\
\hline
\end{tabular}




\begin{tabular}{|c|c|c|c|}
\hline $\begin{array}{l}\text { Increased fragmentation within } \\
\text { PA }\end{array}$ & Low & Medium & \\
\hline $\begin{array}{l}\text { Isolation from other natural } \\
\text { habitat }\end{array}$ & Low & Medium & \\
\hline Other edge effects & Low & Low & \\
\hline Loss of keystone species & Low & Low & \\
\hline \multicolumn{4}{|c|}{ Invasive and other problematic species and genes } \\
\hline Invasive/non-native plants & Low & Low & \\
\hline Invasive/non-native animals & Low & Low & \\
\hline Pathogens & Low & Low & \\
\hline Introduced genetic material & Low & Low & \\
\hline \multicolumn{4}{|c|}{ Pollution entering or generated within the protected area } \\
\hline $\begin{array}{l}\text { Household sewage and urban } \\
\text { wastewater }\end{array}$ & Low & High & \\
\hline $\begin{array}{l}\text { Sewage and wastewater from } \\
\text { PA facilities }\end{array}$ & N/A & Medium & \\
\hline $\begin{array}{l}\text { Industrial, mining and military } \\
\text { effluents and discharges }\end{array}$ & N/A & Low & \\
\hline $\begin{array}{l}\text { Agricultural and forestry } \\
\text { effluents }\end{array}$ & Low & Low & \\
\hline Garbage and solid waste & Low & High & \\
\hline Air-borne pollutants & Low & Low & \\
\hline Excess energy & Low & Low & \\
\hline \multicolumn{4}{|c|}{ Geological events } \\
\hline Volcanoes & N/A & N/A & \\
\hline Earthquakes & N/A & N/A & \\
\hline Avalanches/Landslides & $\mathrm{N} / \mathrm{A}$ & Low & \\
\hline Erosion and siltation/deposition & High & Medium & Common threat \\
\hline \multicolumn{4}{|c|}{ Climate change and severe weather } \\
\hline Habitat shifting and alteration & Medium & Low & \\
\hline Droughts & Medium & Low & \\
\hline Temperature extremes & Medium & Medium & Common threat \\
\hline Storms and flooding & Medium & Low & \\
\hline Changes in species behaviour & Medium & Medium & Common threat \\
\hline \multicolumn{4}{|c|}{ Specific cultural and social threats } \\
\hline $\begin{array}{l}\text { Loss of cultural links/TEK } \\
\text { and/or management practices }\end{array}$ & High & Medium & Common threat \\
\hline
\end{tabular}

* Data was sourced from the CPAMETT database 